\title{
Calculating Financial State Losses due to Corruption in Indonesia: Financial State Losses in WhoseEyes?
}

\author{
Ronald HasudunganSianturi \\ Faculty of Law, Prima Indonesia University, Indonesia \\ hasudungan_r@yahoo.com \\ Theresia Simatupang \\ Faculty of Law, Prima Indonesia University, Indonesia \\ theresia_unpri@yahoo.co.id \\ Rahmayanti \\ Faculty of Law, Prima Indonesia University, Indonesia \\ Rahmayanti888@yahoo.com
}

Doi:10.5901/mjss.2015.v6n3p124

\begin{abstract}
Indonesian regulations authorizestate financial losses calculation to several institutions such as Audit Supreme Board of Republic of Indonesia (BPK), Financial and Development Supervisory Board (BPKP), Inspectorate Agencies, and law enforcement officers (police, prosecutor, and Anti-CorruptionCommission). It becomes a problem if the institutions give different conclusions in financial state losses calculation. As a rule of law, financial state losses calculation should be done using the legality principle where the calculations should be carried out by the competent authority, withproper procedure, and proper substance. This research uses normative juridical research by using legislation theory. The data used is legislation as legal materials data.The results of this study found that the state's financial losses can be caused by an administrative error or corruption. An authorized institutioncalculatingthe financial state losses due to administrative error is Audit Supreme Board of Republic of Indonesia, while the inspectorate calculation can be used if it is not counted by Audit Supreme Board of Republic of Indonesia.An authorized institution calculatingthe financial state losses due to corruption isAnti-CorruptionCommission, while the police and prosecutor can be used if it is not counted by Anti-CorruptionCommission.
\end{abstract}

Keywords: administrative law, calculating, corruption, criminal law, state losses

\section{Introduction}

Stolen asset recovery issue is one of the central issues in the corruption prosecution in every country. UNCAC 2003 put the asset recovery issue in chapter 1as well as (1) preventive measures, (2) criminalization and law enforcement, (3) international cooperation, (4) technical assistance, training and collection exchange, and analysis of information, (5) mechanism for implementation, and (6) final clauses (UNCAC 2003). The ultimate goal of asset recovery is to deprive criminals of their illegally acquired assets and return these assets to their country of origin. As noted by a recent study on asset recovery and development assistance, asset recovery represents a significant improvement when compared withthe traditional focus of law enforcement, which was limited to obtaining a conviction and prison penalty (GrettaFennerZinkernagel, Pedro Gomes Pereira, Francesco De Simone, 2014).

In Indonesia, stolen asset recovery due to corruption is limited to the amount of state assets that should be returned as restitution in the amount specified based on the court's sentence. The compensation is to be paid as an additional criminal convict. If the convicted person doesnot paywithin 30 days, then the assets will be seized and auctioned to pay the compensation. If the convicted person does not have enough assets to pay the compensation, the convict will be penalized imprisonment (Article 18 Indonesian Anti-Corruption Law).

Before making a decision, the judge considered the amount of financial state losses based evidence in the court by the relevant authorities. Determination of the amount of state financial losses becomes a problem becausethe calculation of financial loss to the state is not monopolized by one institution. The authority of the state financial loss calculation is 
owned by Audit Supreme Board of Republic of Indonesia (BPK), Financial and Development Supervisory Board (BPKP), Inspectorate Agencies, and law enforcement officers (police, prosecutor, and Anti-CorruptionCommission).

Ensuring legal rule, various agencies calculating financial state losses require the same perspective to determine the loss of the state and the amount of losses that occurred. However, in practice, various institutions have differing opinions about the state of financial losses. Audit Supreme Board of Republic of Indonesia argues that the state has nolosses if the state losses have been restored, while the law enforcement officers argue that the state's financial indemnification does not remove the element of state financial losses. Also, differences can occur in the method of calculation. The method of calculating financial state losses that can be done by (1) apple to apple comparison method, (2) cost of production method, (3) comparison between the value of the contract with the comparative market price or value of certain methods, and (4) total loss method also resulted in differences in the amount of financial loss to the state (SistemInformasiKeuangan Negara/Daerah, 2012).

According to Indonesian Corruption Watch, institutions that are often included in the calculation of the state's financial losses are: (1) Audit Supreme Board of Republic of Indonesia (BPK) and (2) Financial and Development Supervisory Board (BPKP). Thus, the authority of the state financial losses calculation is not limited to the Audit Supreme Board of Republic of Indonesia and Financial and Development Supervisory Board. Constitutional Court Decision No. 31 I PUU-X / 2012 dated October 23, 2012 allows other agencies to calculate the financial state losses.

The importance of certainty in calculation of financial state losses as a basis for determining the stolen assets recovery requires investigation of the authorities that determine the state of financial losses. This paper investigates the calculation of financial state losses from the laws and regulations perspective by using the law and regulations principles in Indonesia.

\section{Research Method}

The authors decided to use normative juridical research by using regulations as legal materials data. This research was carried out in four phases: (1) Collecting regulation related to state losses calculation, (2) Describing state losses calculation mechanism in Indonesia regulation, (3) Analyzing state losses calculation regulations inkages, (4) Developing recommendations for determining competent institutions in calculating state losses.

\section{Finding}

\subsection{Financial Regulations History in Indonesia}

During the colonial era, Indonesia was known as Dutch East Indies. As a colony, financial management in the Dutch East Indies was governed by IndonesischeComptabiliteit Wet (ICW), which provides state financial control functions to the parliament. Although the ICW had been established since 1917, the Governor-General of the Dutch East Indies has the authority to set a budget without the control of parliament as stipulated in the ICW. State financial oversight started running since 1925 with the establishment of the People's Council that provides oversight authority to control the parliament.

After Indonesian independence, the ICW existed based on Article II Transitional Provisions of Indonesia Constitution 1945. Then, it was amended by Indonesia Law No. 6 of 1968 on State Treasury. Furthermore, the change of paradigm is to build effective state finances that are efficient, consistent, and according to the principles of good corporate governance. The change of paradigm isdone with publishing (1) Law No. 17 of 2003 on State Finance, (2) Law No. 1 of 2004 on State Treasury, (3) Law No. 15 of 2004 on Management and Responsibility of Financial State, and (4) of Presidential Decree No. 42 of 2002 on Guidelines for Implementation of the state budget. Through this law, the previous state financial management is complementary to the bureaucracy of public policy beingconverted into a specific bureaucratic system that needs to be regulated through a specific bureaucracy (W. TiawanTjandra, (2014), HukumKeuangan Negara, Jakarta: Grasindo).

\subsection{RekonstruksiPengelolaandanPengawasanKeuangan Negara}

Financial state system reform has established a new legal framework and provides some important implications in the state finances management through organization reconstruction. Organization reconstruction emphasizes delegation of authority in management and supervision of state finances. 


\subsubsection{Reconstruction of State Financial Management}

Prior to the establishment of legal framework of public finance, public finance waslimited to the state budget that is managed centrally by the president as an executive leader. Implementing the state finance management, the president is responsible to the Assembly as a mandate holder. After fourtimes amendment to the constitution, the state power is divided intofourparts, namely (1) the Executive is the President; (2) the Legislative is the Assembly (DPR) and the House of Representatives (MPR), (3) the Judiciaryisthe Constitutional Court, Supreme Court, and The Judicial Commission, and (4) the Financial Control isAudit Supreme Board of Republic of Indonesia (BPK). In the executive institution, state budget management authority is handled by the President as the chief executive who is assisted by (1) The Minister of Finance as Chief Financial Officer; (2) The minister/head of the institution asChief Operation Officer (COO), and (3) the Central Bank to establish and implement monetary policy. Local budget management authority is also in the hands of the President and the President delegates its authority to the local leader (governors, regents, and mayors) as per(Law No. 23 of 2014 on Regional Government). In the legislative institution, state budget management authority is handled by The Assembly and The Parliament. In the judiciary institution, state budget management authority is handled by the leadership of the Constitutional Court, Supreme Court, and the Judicial Commission.

\subsubsection{Reconstruction of State Financial Management Supervision}

Legal framework of state finances has established surveillance systems to use state finances to minimize mistakes or abuse of authority resulting in losses to the state finances. State finances monitoring system is suppliedthrough (1) internal controls and (2) external supervision. According to Fachruddin (2004), internal control is conducted by a unit thatis structurally still included in the government's organizations, while external control is done by the organization that is structurally outside the government.

Internal control isthe executive through Government Internal Control System. The President delegated to the Minister / Head of Institution, the Governor, the Mayor, and the Regent to organize the internal control system by establishing institutions inspectorate in each institution (Government Regulation of the Republic of Indonesia No. 60 of 2008 on Government Internal Control System). In addition, the internal control in the executive is also done through the Financial and Development Supervisory Board (BPKP) who have task to control financial and development of government (Presidential Decree of the Republic of Indonesia No. 103 of 2001 on the Position, Duties, Functions, Structure, and Work Non-Government Institutions department). In contrast to the executive, the internal control on the legislative and judiciaryis done by inspectorate at each institution.

External control implies the use of state finances of the entire body (executive, legislative, and judicial) conducted by the Audit Supreme Board of Republic of Indonesia based on various laws such as Section 23E paragraph: (1) Indonesia Constitution 1945, Article 1 paragraph 1 Law No. 15 of 2006 on BPK and Article 2, (2) Law No. 15 of 2004 on Management and Financial Responsibility State. The authority of internal and externalcontrol can be seen inFigure 1.

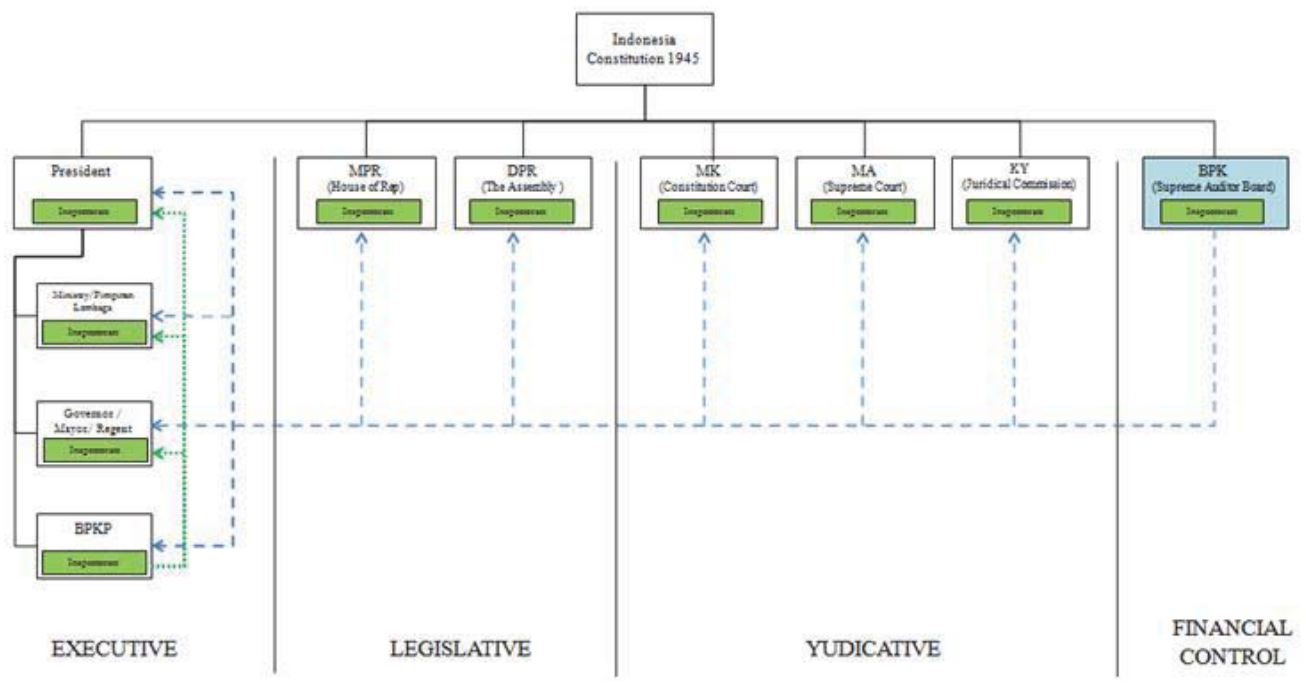

Figure 1. State Financial Control 


\subsection{Financial State Losses Finding due to Corruption and Its Follow-Up}

Internal and external control can find the state's financial losses in the financial management, both in the judiciary and the executive. The findings of the state losses are followed in accordance with the errors committed by state financial managers. Internal control found violations followed by the administration to report to the respective leaders of relevant ministries and institutions. While external control found administration errors, the follow-up is to (1) determine the amount of financial loss to the state and the party is obliged to return loss, (2) supervise the implementation of the return of the financial losses.

Criminals found by inspectors followed up incoordination with law-enforcement agencies in accordance with the authority possessed by each institution. Internal control as Financial and Development Supervisory Board does not have the authority to investigate the handling of cases of financial irregularities in the management of state finances that indicated corruption done by coordinating with the police, prosecutor, and Anti-CorruptionCommission(Memorandum of Understanding between the Prosecutor of the Republic of Indonesia, the Indonesian National Police, and the Financial and Development Supervisory Board No. KEP -A09 / A / JA / 2007, No.POL. B / 2718 / IX / IX / 2007, and No.KEP-1093 / K / D6 / 2007 on Cooperation in Case Handling Deviations of State Financial Management of the Indicated Corruption).

Financial and Development Supervisory Board has also been coordinating with the Anti-Corruption Commission to (a) support the investigative audit, (b) submission of the case, as indicated by corruption, (c) the calculation of losses to the state aid, (d) provision of expert testimony, (e) corruption prevention programs, (f) the dissemination of anticorruption, (g) education and training, (h) the exchange of information related to cases of corruption (Decision of the Joint Commission and the Head of BPK April 30, 2007 on cooperation Pidan Corruption Eradication). Different frominternal control, the Audit Supreme Board of Republic of Indonesia has the authority to conduct investigative audit to find indications of corruption. Cooperation with law enforcement officials conducted after the Audit Supreme Board of Republic of Indonesia found corruption indications of investigative audit results.

\section{Discussion}

\subsection{Rule of Law Principle in Indonesia}

Article 1 point (3) Indonesia 1945 Constitution states that Indonesia is a country of law. According to Philip M. Hadjon(2011), the principle of rule of law state is the principle of legality. Based on the principle of legality, every act of government must be based on (1) the legal authority, (2) proper procedures, and (3) the substance of the right. As a state law, state financial loss calculation should be done using the principle of legality where the calculations should be carried out by the competent authority to use the procedure and substance of appropriate legislation. Based on the principle of legality, the calculation of state financial losses can only be carried out in accordance with the laws and regulations with regard to the principle of lexsuperioriderogatlegiinferiori, the principle of lexspecialisderogratlegigenerali, and the principle of lexposterior derogatlegipriori.

The principle of lexsuperioriderogatlegiinferiori stated that regulations are above and override rules below. In Indonesia, the principle of lexsuperioriderogatlegiinferiori reflected in the Law 12 of 2011 on the Establishment of legislation that states the force of law in accordance with hirearki legislation consists of (1) 1945, (2) MPR Decree (3) Law I Government Regulation in Lieu of Law (regulation) (4) government regulation (5) Presidential Decree (6) Provincial Regulation, and (7) District Regulation. In addition, there arealso recognized rules and have binding legal force throughout ordered by Legislation higher or formed under the authority of such rules established by the People's Consultative Assembly, House of Representatives, Regional Representatives Council, the Supreme Court, Constitutional Court, Audit Board, the Judicial Commission, Bank Indonesia, the Minister, body, agency, or commission level formed by Law or Government at the behest of the Act, the Provincial House of Representatives, Governor, House of Representatives District / City, Regent / Mayor, Village Head, or equivalent.

The principle of lexspecialisderogratlegigeneralistates that there are specific rules that override the general rules. This principle is reflected in (1) Article 63 Point 2 of the Code of Criminal Justice Act, which states that "If a deed entered into a common criminal rule, regulated in a special criminal rule, then that's just the special ones are applied." (2) Article 1 of the Law on Commercial Law states "For the book of this Act to the Code of Civil Law held no particular deviation, then the Code of Civil Law applies also to the things spoken of in the Book of the Law."This principle can only be used if both rules are in the same position on hirearki legislation.

The principle of lexposterior derogatlegipriori states that the new rules overriding the old regulations were equal. The principle of Lex Posterior derogatlegi Priori can be seen from the legislation, which generally states that the 
regulations are still applicable to the extent not in conflict with the old regulations.

In the event of any discrepancy in the state loss calculation performed by the authority by the regulations, the determination of the competent institutions calculate that losses to the state should be based on the principles of the rule of law, namely the principle of lexsuperioriderogatlegiinferiori, the principle of lexspecialisderogratlegigenerali, and the principle of lexposterior derogatlegipriori.

\subsection{Authority of the State Financial Losses Calculation on Administrative Law and Criminal Law}

Regulation principles that provide the state financial losses can be seen in (1) the perspective of administrative law when state financial loss is caused by an administrative error, which resulted in perpetrators accountable administration and (2) the perspective of criminal law when state financial loss is corruption, which resulted in criminal perpetrators responsible.

On the one hand, internal and external oversight is part of the administrative law that is based on the principle of lexspecialisderogatlegigenerali the state financial losses calculated by the internal and external supervisory and administrative impact cannot be used in criminal law enforcement. On the other hand, the calculation of losses to the state as part of criminal law enforcement cannot be done by the internal auditor and external monitoring, but should be done by law enforcement officers with reference to the formal criminal law.

In accordance with the formal criminal law,there are three criminal law enforcement stages: (1) the initial investigation that the research activities undertake to determine whether or not it is a crime, (2) investigation that the activities undertake to make light of an incident of crime by gathering evidence, (3) the prosecution.Authorized agency in the enforcement of criminal law in corruption are: (1) The police has the duty of inquiry and investigation by Act No. 2 of 2002 on the Indonesian National Police. (2) The Attorney General has a duty to prosecute under Law No. 16 of 2004 on the Prosecutor of the Republic of Indonesia, and (3) Anti-Corruption Commission, which has the task of investigating, investigation, and prosecution by Law No. 30 of 2002 on the Anti-Corruption Commission. Although the authority of the state financial loss calculation is not stated explicitly in the legislation mentioned above, the authority is included as part of the inquiry, investigation, and prosecution as provided in formal criminal law in Indonesia.
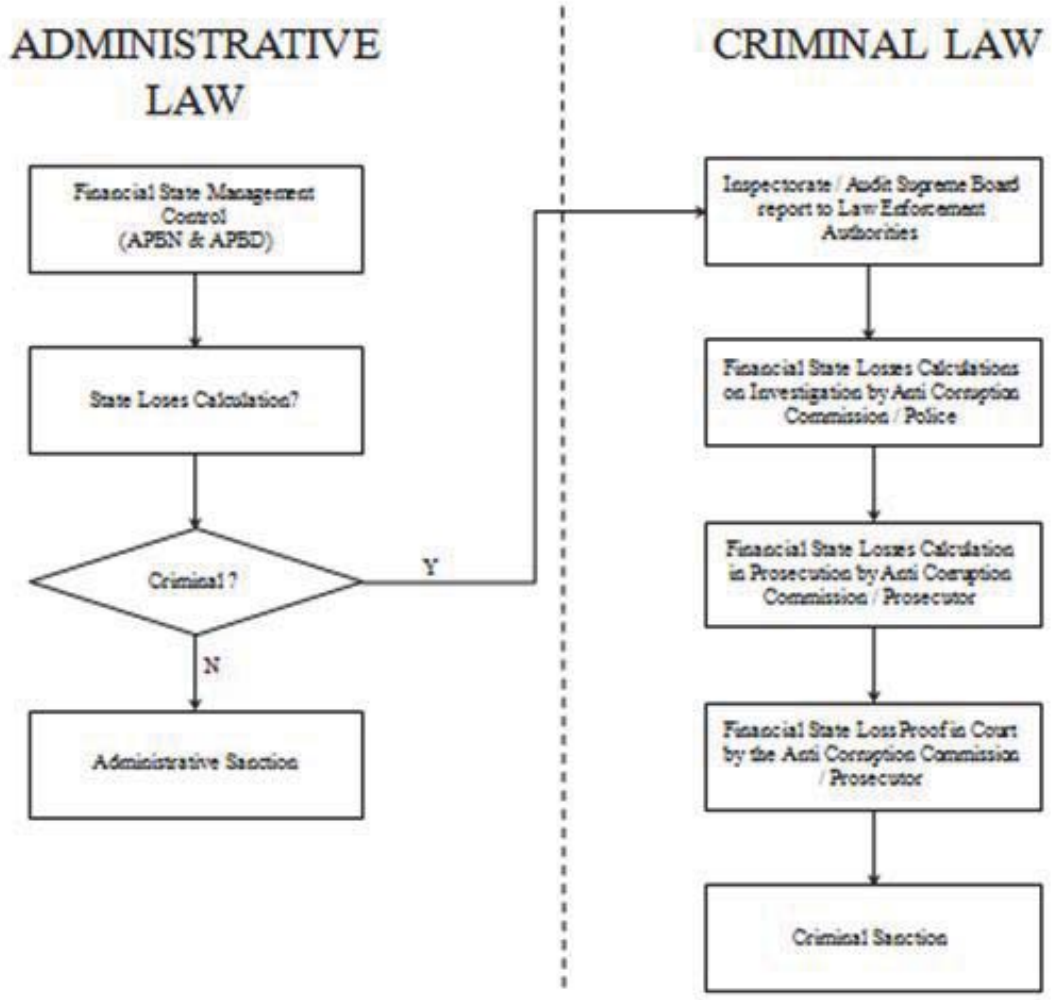

Figure 2. State Financial Losses Calculation Process 


\subsection{Difference Calculation on Administrative Law and Criminal Law}

The number of parties who have authority to calculate the financial losses resulting state does not rule out differences in the results of the calculation of financial loss to the state. That difference can occur among inspectorate (internal control), the inspectorate with external control, or even between internal control with law enforcement officer. In case the differences in the calculation aredone in administrative law,the error issolved by using the principle of lexsuperioriderogatlegiinferiori and the principle of lexspecialisderogatlegigenerali as follows:

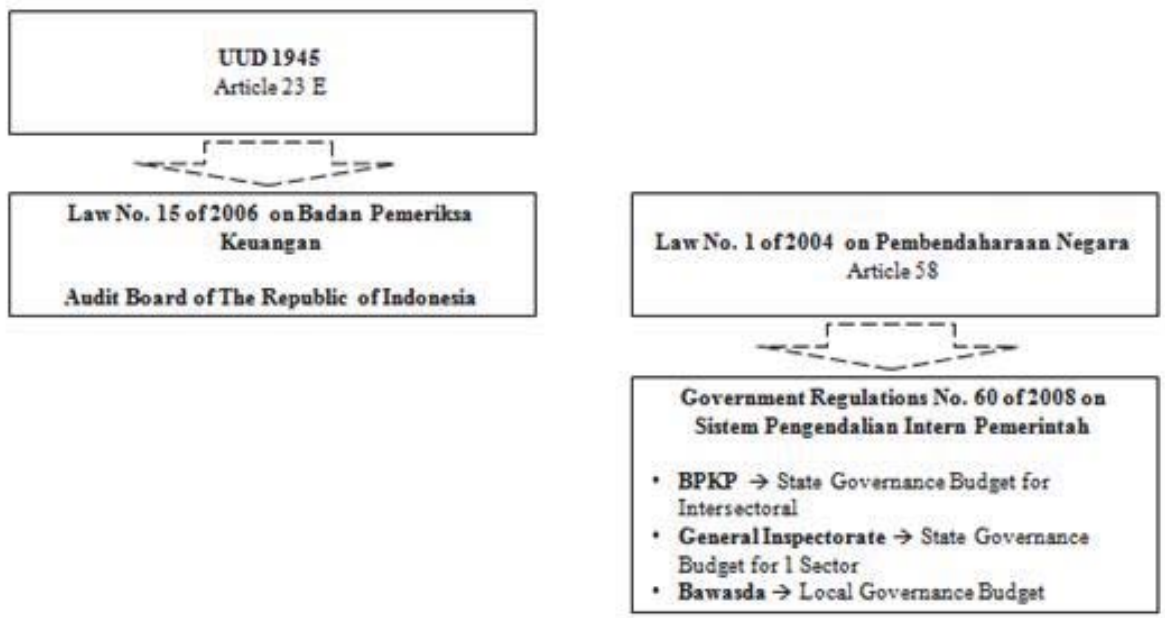

Figure 3. Lexsuperioriderogatlegiinferiori principle in financial state losses calculation

Based on the above scheme, the calculation of the difference between the internal control (Audit Board of The Republic of Indonesia and general inspectorate), the calculation of financial state losses refers to the principle of lexsuperioriderogatlegiinferiori; so,the calculation used is the calculation of the Audit Board of The Republic of Indonesia because it is based on Indonesian Constitution 1945.

In terms of differences in the calculation of financial loss to the state that occurred between sesame General Inspectorate, the calculation of financial loss to the state refers to the principle of Lexspecialis. Based on this principle, the calculation of the financial losses, which refers to the use of state finances, namely (1) Audit Board of The Republic of Indonesia when the state financial authorities used cross-cutting, (2) General Inspectorate to use state funds of a certain sectoral, and (3) Provincial Inspectorate/Inspectorate District/City to use Governance Local Budget.

Unlike the administrative law, criminal law enforcement corruption calculation based on Law No. 30 of 2002 on the Anti-Corruption Commission provides that the Commission has authority to conduct supervision over the corruption cases. Thus, the calculation of the financial loss that is used is a version of the Anti-Corruption Commission. The calculation of the financial state losses made by the police and the attorney can be used if the case has not been supervised by the Anti-Corruption Commission.

\section{Conclusion}

Financial state lossesarerelated to administrative law and criminal law; so, it should be based on the rule of law principle of the legislation to avoid the mistakes of the implementation of legislation.

In case of administrative law error, the calculation of state assets used is the calculation of the Audit Supreme Board of Republic of Indonesia in accordance withlexsuperioriderogatlegiinferiori principle. In terms of differences in the calculation of financial state losses made by the inspectorate, the calculations used by lexspecialisderogratlegigeneraliprinciple depends on the parties that usestate finances.

In case of criminal law error, the calculation used is the calculation of the Anti-Corruption Commission. The calculation of losses to the state by the Police and the Attorney can be used throughout the calculation of the AntiCorruption Commission, which has not been done earlier. 


\section{Acknowledgment}

The authors express their gratitude to The Ministry of Research, Technology and Higher Education of the Republic of Indonesia for the research grant.

\section{References}

BadanPemeriksaKeuangan (2015). SistemInformasiKeuangan Negara/Daerah, MetodelogiPerhitunganKerugianKeuangan Negara. [Online] Available: http://sikad.bpk.go.id/mp_teori.php (February 4, 2015)

Fachruddin, Irfan (2004). PengawasanPeradilanAdministrasiTerhadapTindakanPemerintah, Bandung, Alumni.

Hadjon, Philipus M., Tatiek Sri Djatmiati, G.H. Addink\& J.B.J.M. Ten Berge (2011). HukumAdministrasidanTindakPidanaKorupsi. Yogyakarta: Gajah Mada University Press.

Indonesia (1945).Indonesia Constitution Year 1945.

Indonesia (1999). Indonesia Law No 31 of 1999 on PemberantasanTindakPidanaKorupsi

Indonesia (2001). Indonesia Law No 20 of 2001 on PerubahanAtasUndang-Undang No. 31 Tahun 1999 tentangPemberantasaKorupsi

Indonesia (2001).Presidential Decree of Republic Indonesia No. 103 of 2001 on Kedudukan, Tugas, Fungsi, Kewenangan, SusunanOrganisasidan Tata KerjaLembagaPemerintah Non Departemen.

Indonesia (2002). Indonesia Law No. 30 of 2002 on KomisiPemberantasanKorupsi

Indonesia (2002).Presidential Decree of Republic Indonesia No. 42 of 2002 on PedomanPelaksanan APBN.

Indonesia (2004). Indonesia Law No. 1 of 2004 on Pembendaharaan Negara.

Indonesia (2004). Indonesia Law No.15 of 2004 on PemeriksaanPengelolaandanTanggungJawabKeuangan Negara.

Indonesia (2006). Indonesia Law No. 15 of 2006 on BadanPemeriksaKeuangan.

Indonesia (2008).Government Regulation of Republik Indonesia No. 60 of 2008 on SistemPengendalian Intern Pemerintah.

Indonesia (2011). Indonesia Law No. 12 of 2011 on PembentukanPeraturanPerundangan.

Indonesia (2012).Constitutional Court Decision of Republic Indonesia No. 31/PUU-X/2012.

Indonesia (2014).Indonesia Law No. 23 Tahun 2014 on Pemerintahan Daerah.

Indonesia Corruption Watch(2014).Research Report PenerapanUnsurMerugikanKeuangan Negara dalamDelikTindakPidanaKorupsi, Policy Paper, Maret 2014.

Tjandra, W. Tiawan (2014). HukumKeuangan Negara, Jakarta: Grasindo.

United Nation (2003). United Nation Convention Against Corruption 2003.

Zinkernagel, G. F., Pedro Gomes Pereira, Francesco De Simone (2014). The Role of Donors in the Recovery of Stolen Assets, International Centre For Asset Recovery Working Paper Series 17, December 2014. 